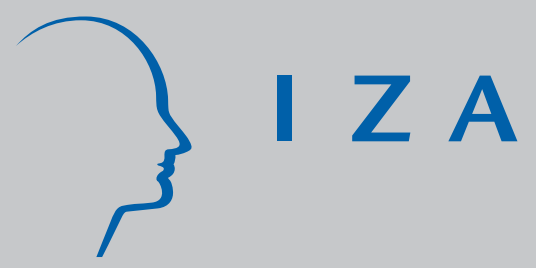

IZA DP No. 4055

EU Enlargement under Continued Mobility Restrictions: Consequences for the German Labor Market

Karl Brenke

Mutlu Yuksel

Klaus F. Zimmermann

March 2009 


\title{
EU Enlargement under Continued Mobility Restrictions: Consequences for the German Labor Market
}

\author{
Karl Brenke
}

DIW Berlin

Mutlu Yuksel

IZA

\author{
Klaus F. Zimmermann \\ IZA, Bonn University and DIW Berlin
}

Discussion Paper No. 4055

March 2009

\author{
IZA \\ P.O. Box 7240 \\ 53072 Bonn \\ Germany \\ Phone: +49-228-3894-0 \\ Fax: +49-228-3894-180 \\ E-mail: iza@iza.org
}

\begin{abstract}
Any opinions expressed here are those of the author(s) and not those of IZA. Research published in this series may include views on policy, but the institute itself takes no institutional policy positions.

The Institute for the Study of Labor (IZA) in Bonn is a local and virtual international research center and a place of communication between science, politics and business. IZA is an independent nonprofit organization supported by Deutsche Post Foundation. The center is associated with the University of Bonn and offers a stimulating research environment through its international network, workshops and conferences, data service, project support, research visits and doctoral program. IZA engages in (i) original and internationally competitive research in all fields of labor economics, (ii) development of policy concepts, and (iii) dissemination of research results and concepts to the interested public.
\end{abstract}

IZA Discussion Papers often represent preliminary work and are circulated to encourage discussion. Citation of such a paper should account for its provisional character. A revised version may be available directly from the author. 


\section{ABSTRACT}

\section{EU Enlargement under Continued Mobility Restrictions: Consequences for the German Labor Market}

The numbers of migrants from the accessions countries have clearly increased since the enlargement of the EU in 2004. Following enlargement, the net inflow of EU8 immigrants has become 2.5 times larger than the four-year period before enlargement. Poles constitute the largest immigrant group among the EU8 immigrants: since enlargement, $63 \%$ of all immigrants and $71 \%$ of EU8 immigrants are from Poland. This chapter presents new evidence on the impact of immigrant flow from EU8 countries on the German labor market since EU enlargement. Unlike other EU countries, Germany has not immediately opened up its labor market for immigrants from the new member states. Nevertheless, our analysis documents a substantial inflow and suggests that the composition of EU8 immigrants has changed since EU enlargement. The majority of the new EU8 immigrants are male and young, and they are less educated compared to previous immigrant groups. We also find that recent EU8 immigrants are more likely to be self-employed than employed as a wage earner. Furthermore, these recent EU8 immigrants earn less conditional on being employed or selfemployed. Our findings suggest that these recent EU8 immigrants are more likely to compete with immigrants from outside of Europe for low-skilled jobs instead of competing with German natives. While Germany needs high-skilled immigrants, our analysis suggests that the new EU8 immigrants only replace non-EU immigrants in low-skilled jobs. These results underline the importance of more open immigration policies targeting high-skilled immigrants. The current policy not only cannot attract the required high-skilled workforce, but also cannot avoid the attraction of low-skilled immigrants, and is a complete failure.

JEL Classification: J61, F22, E24

Keywords: EU enlargement, international migration, wages, employment

Corresponding author:

Klaus F. Zimmermann

IZA

P.O. Box 7240

D-53072 Bonn

Germany

E-mail: Zimmermann@iza.org

\footnotetext{
* We would like to thank the Statistisches Bundesamt (German Federal Statistical Office) and the Statistical Offices of the Bundesländer for allowing us to use the Microcensus data through the Forschungsdatenzentrum Berlin-Brandenburg. We thank in particular the staff of the Forschungsdatenzentrum for valuable assistance.
} 


\section{Introduction}

Germany has been experiencing a large inflow of immigrants for at least the last four decades. Post Second World War labor immigration into Germany began during the 1960s and 1970s, when Germany invited approximately 3 million guest-workers especially from Southern Europe, the former Yugoslavia and Turkey. Since reunification some 15 years ago, 2.5 million people from Eastern Europe have moved to Germany. Immigration has kept Germany's population constant since the enlargement of the European Union in the spring of 2004.

According to the Central Register of Foreigners, the total number of immigrants between the age of 15 and 65 in Germany at the end of 2007 was close to 5.5 million, or approximately $10 \%$ of the total population in that age group. Immigrants from EU8 countries constituted only $9.3 \%$ of all immigrants at the end of $2007 .{ }^{1}$ However, net inflows have been increasing from the new member states into Germany despite a “closed door” ${ }^{2}$ policy aimed at restricting immigration.

A number of recent studies extensively analyze migration intentions, determinants and scale of migration, effects of the post-enlargement migration flows on the receiving as well as the sending countries' labor markets, welfare systems, and growth and competitiveness for all European countries after EU enlargements (Kahanec and Zimmermann, 2008; Fouarge and Ester, 2007a, 2007b; Bonin et al., 2008; Zaiceva and Zimmermann, 2008; De Giorgi and Pellizzari, 2006; Blanchflower and Lawton, 2008).

\footnotetext{
${ }^{1}$ The percentages of immigrants from the more traditional source countries are as follows: $24.6 \%$ of the 5.5 million are from EU15 countries; 24.1\% from Turkey; 13.2\% from the former Yugoslavia; 5\% from the exSoviet Union; and 20.1\% from outside of Europe.

${ }^{2}$ For more detailed information see Brenke and Zimmermann (2007).
} 
This chapter adds to this strand of literature. Here, we investigate the influx of recent EU8 immigrants, their characteristics and how they impact the German labor market. In the next section, we provide the legal framework governing Germany’s restrictive policy, and any exceptions made for new immigrants. In section 3, recent migration and the background of EU8 immigrants are studied. In section 4, we offer a broad picture of the main characteristics of this group of immigrants, their observed skills and their labor market outcomes. Section 5 compares the labor market situation of these recent EU8 immigrants to that of other immigrant groups and natives. Finally, section 6 discusses the main findings and provides some immigration policy recommendations in view of the results.

\section{The Legal Framework}

During the negotiations regarding the enlargement of the EU which took place on May 1st 2004, the individual countries of "old” Europe (EU15) were able to decide for themselves how far they would relax their border restrictions for new migrants from the new member states. Germany has since had a restrictive policy and denied both workers and companies from the accession countries complete freedom, with the exceptions of Cyprus and Malta. Therefore, Germany, together with Austria, are unique because they are the only member states which have not extensively relaxed restrictions on migrants from the accession countries of 2004. However, holes have appeared in the fence which has been raised to block immigrants from the new member states. The following summarizes the exceptions for workers and businesses. 
Self-employed workers from the EU8 are allowed to settle in Germany and run a business. However, they may not employ workers from their home country. Temporary work permits are given to employees from EU8 countries (including Bulgaria and Romania), but only if German workers or established immigrants are not put at a disadvantage. ${ }^{3}$ Further training can also count as employment. In 2007, government job agencies issued 61,000 work permits (without seasonal workers, domestic servants) for EU8 citizens and 19,000 for workers from Bulgaria and Romania. It should also be said, however, that 12,000 applications from the new member states were rejected. ${ }^{4}$ In addition to these permits, 286,000 seasonal working permits were issued, where $79 \%$ were used by Poles.

Even though politicians evidently expect German companies to face strong competition - especially due to lower wages - and have restricted the free movement of most services, businesses of certain sectors can operate with different permits. For instance, the IT industry or consultation companies can operate freely in Germany, and they may also employ workers from abroad. However, some foreign companies are allowed to be active in sectors such as the building industry, the decorating business, and cleaning companies but only with so-called "key personnel", who are "management and personnel with the qualifications and expertise for the job or area of work, and skills which are necessary for the home (German) company base.” 5

\footnotetext{
${ }^{3}$ See $\S 284$, Abs. 1 SGB III. SGB means Sozialgesetzbuch (social law).

${ }^{4}$ See Bundesagentur für Arbeit (2008).

${ }^{5}$ See Christen (2004).
} 
The other exceptions are so-called "contingency contracts", which are mainly for farm helpers, and "special contracts" for high-skilled workers. Such contingency contracts have been around for decades and are not just associated with the enlargement process. These types of contracts are mainly established by bilateral agreements between Germany and certain EU8 countries, and they are referred to as "contingent labor forces", which are for workers who only stay in Germany for a specific period of time.

Generally, the immigration of high-skilled workers is possible, especially in the IT industry, but this is not related to EU8 expansion. The earnings are fixed for this type of immigrants, who need to earn in Germany a minimum gross annual salary of 86,400 euros. However, as few people immigrated to Germany as a result, the German government in the summer of 2007 decided to lower the limit to 63,600 euros. ${ }^{6}$ In addition, there are also special rules for individual professions e.g. scientists working in research or people who work at fairgrounds. These high-skilled permits are issued in very low numbers relative to the total number of work permits issued in Germany. Ultimately, it is also possible for a foreigner outside the EU15 to obtain a work permit by marrying a German national.

There has been little debate or disagreement between the political parties on limiting access to Germany for immigrants from EU8 countries. Therefore, it is expected that Germany’s current policy will remain until 2011, when the transitional period of the free movement of workers and services expires. This is all the more likely given the slowing down of the economy since 2008.

\footnotetext{
${ }^{6}$ Numbers for the issued work permits for IT workers exist only for countries outside of the EU. This number was 3,400 in 2007. See Bundesagentur für Arbeit (2008).
} 


\section{Migration Movement and Background of People from EU8 Countries.}

The following findings are based on two official data sources on the population from regional registry offices in the community (“örtliche Melderegister”) and the Central Registry of Foreigners (“Ausländerzentralregister”). The data sets contain personal information about immigrants (and emigrants) such as age, sex, nationality and length of stay.

Table 1 presents annual inflows and net migration numbers in Germany from different countries, including EU8 countries, from 2000 to 2006. The number of migrants from the accessions countries has clearly increased since the enlargement in 2004. The net gain of EU8 immigrants is 2.5 times larger than in the four-year period before enlargement. Had it not been for migration from the EU8, Germany would have had a net loss of migration. A decrease of net-migration resulted from a more than $50 \%$ drop in the number of immigrants from other important source countries, including Turkey, Russia and Ukraine, along with countries further outside Europe. The outflows of German citizens and EU15 immigrants have been higher than the inflows, resulting in a net loss over the last 2 years. The total net gain is predominantly caused by Polish migration and is at around $65 \%$.

[Table 1 here]

As mentioned above, Poland, responsible for $71 \%$ of EU8 immigrants, is the major source country for EU8 migration. Hungary is the second most significant source country 
and Estonia the least. ${ }^{7}$ For each EU8 immigrant living in Germany, there are 116 who live in the home country. Poles clearly dominate the recent immigrant flow. That is not surprising given that Poland is by far the most populated of the EU8 countries. Similar vein, if the number of immigrants in Germany is compared to their source country's population, Poles rank clearly above the other EU8 countries as well. In particular, for each Polish immigrant living in Germany, there are 81.4 Poles residing in Poland. Relatively few migrants come from the Czech Republic ${ }^{8}$, which is surprising given its proximity to Germany. This may indicate that recent EU8 migration is intentionally temporary.

When we analyze the distribution of recent immigrants according to age cohorts, we find evidence suggesting that EU8 immigrants' main aim when migrating to Germany is employment. Immigrants from EU8 countries mainly comprise of those in the age group 25 to 45. For every immigrant in Germany from an EU8 country aged between 25 and 35, there are 66 people of the same age living in the EU8 countries. ${ }^{9}$ Furthermore, immigrants from the EU8 who have migrated after 2004 have migrated with fewer children than other immigrants: $14.7 \%$ of other immigrants and only $5.4 \%$ of EU8 immigrants were younger than 15 years old in 2007. However, it is quite likely that their children have remained in the source country.

\footnotetext{
${ }^{7} 10 \%$ from Hungary, 6\% from the Czech Republic, 4\% from Slovakia, 3\% from Slovenia and Lithuania, $2 \%$ from Latvia and $1 \%$ from Estonia.

${ }^{8}$ For each Czech immigrant in Germany, there are 356 Czechs living in the Czech Republic; 1:342 for Hungary; 1:265 for Estonia; 1:219 for Slovenia; 1:195 Latvia; 1:139 Lithuania; 1:64 Slovakia

${ }^{9}$ One immigrant who is in the same age cohort living in Germany to 310 people who are between 15 to 20 years old living in the EU8 countries; 113 aged 20 to 25; 88 aged 35 to 45; 121 aged 45 to 55; 212 aged 55 to 65 .
} 
When we explore the composition of recent immigrants by gender, there is a slight decline in the share of working age females amongst EU8 immigrants, which decreased from $55.3 \%$ in 2004 to $52.7 \%$ in 2007. Furthermore, the share of women increased from the Baltic States and the Czech Republic during the same period. However, these national groups have fewer immigrants in Germany, which is in contrast to Poles, whose numbers have disproportionately increased, with the share of Polish women decreasing by around 4 percentage points ${ }^{10}$ in 2007. There are also gender differences along with age differences between immigrant cohorts from these countries. For instance, there were twice as many men as women aged between 25 and 34 who migrated in the period 2005 to 2007.

Not only do men have higher levels of immigration, but they have been more likely to leave Germany since 2004. Both male inflow and outflow numbers are larger than those of females, and hence, so are the net migration numbers. In 2007, one quarter of EU8 immigrants stayed less than a year in Germany, and 70\% stayed less than three years. Compared to the earliest data, which are from 2005, the average duration of residence has risen considerably for EU8 immigrants; while it has remained the same for EU15 and non-EU immigrants.

To summarize, there was a definite increase in immigration to Germany after EU enlargement. There would have been a net loss of migration as early as 2006 without immigrants from EU8 countries, mainly Poland. The migration flow after EU enlargement has consisted mostly of Polish migrants, especially men, who have moved to

\footnotetext{
${ }^{10}$ In 2007, the share of females from Estonia was 74.2\%; Latvia 69.8\%; Lithuania 73.8\%; Poland 51.1\%; Slovakia 59\%; Slovenia 51.9\%; the Czech Republic 67.7\%; and Hungary 40.8\%.
} 
Germany, and migrants from the EU8, which have exhibited large fluctuations. The most significant group is aged between 25 and 45; hence, few children have migrated. This suggests that migration was not permanent by intention, but has been a planned temporary move to Germany.

\section{Descriptive Statistics}

Although the data in the registry contains information on age, sex, nationality and length of stay, it does not provide much information about the socio-economic characteristics of immigrants in Germany. Therefore, we use microcensus data, which are based on an official survey of households obligated to give information. The microcensus includes $1 \%$ of the resident population, and it is a large, representative, random sample containing comprehensive information on socio-demographic and economic characteristics of individuals in Germany. We use data from the 2006 wave, with approximately 380,000 households and 820,000 people in total, which are generally based on face-to-face interviews. The survey also contains information on all household members and has a very high response rate of approximately $97 \%$.

Table 2 reports detailed information from the 2006 microcensus on the labor force participation, employment status, and occupational skill levels according to the source country of the immigrant. EU8 immigrants are divided into two sub-groups of those who migrated before 2004 and those after. The labor force participation rate of EU8 immigrants is lower compared to Germans and EU15 immigrants but higher than or equal to immigrants from other countries. The unemployment rate of recent EU8 immigrants is much lower compared to other immigrants. However, when we exclude students who are 
also employed, the unemployment rate is about 20\% for recent EU8 immigrants and nearly the same as the rate for earlier ones from the EU8. Moreover, the percentage of students from EU8 countries increased from $10 \%$ to $15 \%$ after enlargement. Although EU15 citizens have free access, recent years have seen a decrease in their migration to Germany.

[Table 2 here]

Even though the employment rate is higher for EU8 immigrants compared to other immigrants, half of the employed EU8 immigrants are self-employed or work in part-time or mini-jobs ${ }^{11}$. This may be due to legal restrictions faced by EU8 migrants who live in Germany which act as a barrier to the labor market. The percentage of selfemployed immigrants is generally higher than native Germans, with the exception of people from Turkey and South-East Europe. The incidence is especially high for people from the EU8. Obviously, many EU8 immigrants have taken advantage of the opportunity made possible by EU enlargement to take up residence in Germany and become self-employed. This finding probably has to do with the fact that such employment is often associated with simple unskilled jobs. Alternatively, it might be that the type of work an immigrant tends to do is in a legal gray zone or is in fact illegal. It could explain why many immigrants, both from the EU8 and non-EU countries, are marginally employed. Exceptions to this are people from Turkey and the former Yugoslavia: national groups which belonged to an earlier guest worker program. Table 2

\footnotetext{
${ }^{11}$ A mini-job is a form of employment in which up to 400 euros a month can be earned without having to pay any tax or social security contributions. The employer has to make a small social security payment. However, there may also be comparable employment arrangements in an illegal form.
} 
also shows that more than half of all immigrant groups reside in the core cities of metropolitan areas. The figures are similar for recent and earlier EU8 immigrants, where $42 \%$ and $43 \%$ of them live in big metropolitan cities, respectively. This finding suggests that immigrants are attracted by the economic opportunities to be found in big cities. It also seems that enclave networks are important in the choice of residence.

The main interest group is EU8 immigrants, and five main subgroups of the total sample are defined and presented in the following empirical analysis. The first distinction leads to two groups which are based on the criteria of having German nationality. The first group is called "native” and includes those born in Germany and with German nationality since birth. The second group is called "native-others" and contains individuals who were born in Germany but naturalized later (such as second generation immigrants), or who migrated to Germany and have only German nationality (such as ethnic-Germans). Immigrants form the remaining population and are divided into 3 subgroups. The first sub-group is called "EU8" and constitutes immigrants who migrated from and are a national of an EU8 country. The second sub-group is called "EU15" and includes migrants from EU15 countries and the US. The last sub-group is called "nonEU” and covers those from non-EU countries, mainly Turkey, Africa, the Middle East and Asia. Furthermore, individuals who immigrated to Germany before and after the 2004 enlargement were also separately analyzed for each of the groups. The target group that we mainly focus on in our analysis is "recent EU8 immigrants", who migrated from enlargement countries after 2004. For a detailed analysis, we also separate all immigrants groups into two by their year of migration, where "recent" refers to the immigrants who migrate after 2004, and "earlier" refers to the ones that migrated before 2004. 
EU8, non-EU, EU15 and native-others constitute 1\%, 10\%, 3\% and 5\%, respectively, of the weighted sample containing all individuals who are aged between 15 and $65.7 \%$ of all immigrants are from EU8 countries, 22\% from EU15, and the remaining $71 \%$ are from other countries in our sample. Immigrants from EU8 countries generally migrate at older ages compared to immigrants from all other countries. However, they are also on average more educated than other immigrant groups. The mean age at migration of a EU8 immigrant is 26; whereas it is around 22 for other immigrant groups. On the other hand, if we only focus on immigrants who arrived just 3 years before and after enlargement, we have a different picture. The average age at the time of migration is 32 for an immigrant from the EU15 and 29 for a non-EU country. Furthermore, this average age is the same before and after enlargement. However, an EU8 immigrant's average age at migration was 27 before enlargement, and the mean age of recent immigrants is 31 years old. These figures hint that EU enlargement might have altered the composition of immigrants from EU8 countries, which we will analyze in detail in the remainder of the chapter.

Figure 1 presents the stock of EU8 immigrants in 2006 by year of arrival and gender, where the years of arrival are divided into 3-year intervals. In order to calculate the stock, we take the number of male immigrants in 2006 from a year of arrival interval and divide this by the total number of males in 2006 and then multiply this share by 100 to express it in percentage points. Female stock percentages are calculated similarly. EU8 immigrants are divided into 12 categories by year of migration providing information on immigrants who migrated between 1971 and 1973, and so forth until 2004 and 2006, which contains the most recent after enlargement influxes of EU8 migrants to Germany. 
The stock of EU8 immigrants who migrated between 1989 and 1991 constitutes 0.19\% for all females and $0.17 \%$ for all males in 2006. After the collapse of the Berlin Wall, there was a dramatic increase in migration from EU8 countries, and then it fell steeply until 1995. After 1995, migration from these countries started to increase once more with the percentage of females from the EU8 reaching $0.19 \%$ at the point of EU enlargement. On the other hand, the share of EU8 male immigrants increased to $0.13 \%$ after 2004, but it is still lower than the percentage of female migrants from these countries. The percentage of recent immigrants (those who migrated between 2004 and 2006), other immigrant groups and the immigrants who migrated between 2001 and 2003 are the same or have decreased.

[Figure 1 here]

The microcensus data provides information on the highest secondary school degree acquired and information related to the type of vocational training that the individual has received. These two variables allow us to construct a continuous measure of years of education. The mean year of schooling is 13.3 years for EU8 immigrants and 12.6 for non-EU immigrants. However, a more detailed analysis reveals that differences in educational attainment have been decreasing over time between those two groups, which we will incorporate in our analysis.

Figure $2 \mathrm{a}$ and $2 \mathrm{~b}$ show the average years of education of immigrant males and females according to the year of arrival in Germany. After 1990, the average years of schooling for immigrant males increased for all immigrant groups. However, before enlargement the average education of EU8 immigrants was higher than of non-EU immigrants and the EU15 group before 2000. The picture has changed since 2004: the 
average education of recent male EU8 immigrants as become the lowest among all recent male immigrants from non-EU countries. This could suggest that a cohort of lower educated immigrants from the EU8 have migrated to Germany since enlargement. Albeit, there is a slight decrease in the average years of education of male immigrants from EU8 countries; however, this may be true only for this period. The questions regarding this issue will be better addressed once more recent data become available. On the other hand, figures show that more educated immigrants from non-EU countries migrated to Germany in the last decade and less educated ones left, so the average education has increased for this group. However, the situation is different for females. After 1990, with the collapse of the Berlin Wall, the average education of female immigrants from the EU8 was higher than that of males. Even after enlargement, there has still been an increasing trend in average educational attainments of EU8 females, whose average education is higher than female immigrants from non-EU countries.

[Figure (2a, 2b) here]

In order to understand the characteristics of recent EU8 immigrants better, we also broaden our analysis to the federal state level. After enlargement, as with all other immigrant groups in Germany, there are no or very few recent EU8 immigrants in the states of Saarland, Brandenburg, Mecklenburg-Vorpommern, Saxony and Thuringia. This may indicate that recent EU8 immigrants prefer to migrate for economic reasons, since they prefer to migrate to states where job opportunities are high. On the other hand, these figures also suggest that the existence of earlier immigrants from EU8 countries in certain states or cities might lead to more recent immigrants from those countries. To put some context to this issue, Hamburg has the largest EU8 immigrant population, at 
approximately $2 \%$ of the total population of the state and $12 \%$ of them are postenlargement EU8 immigrants. Furthermore, 1\% of the population in the Rhineland is from an EU8 country, and 25.3\% of those came after enlargement. Recent EU8 male immigrants who live in Bavaria have the lowest average years of education, 12.2 years, and are relatively older than those who live in other states, with an average age of 35.3 years. On the other hand, Berlin and Hamburg attract relatively younger immigrants, who are 27 years old on average at the time of migration and have the highest average years of education with 14.3 years.

Unfortunately, the microcensus data set does not contain information regarding the wages of individuals; instead, it has information concerning the "main source of income» ${ }^{, 12}$. We only use the information on net monthly income if the individual reports that the "main source of income" is from "working in a job”. We also disregard earnings obtained while at school, or during vocational training or maternity leave. The net monthly income is reported in intervals with 24 income brackets in all. This variable is converted into a continuous variable by taking the midpoint of each interval. Furthermore, we calculate hourly wages by dividing the monthly net income by 4 times the weekly hours worked. Employed people are all those who are 15 and older and have worked at least one hour in the reference week.

It is observed from raw data that EU8 immigrants earn less on average. Average income is 1,652 euros for EU8 men and 1,051 euros for women, while native men earn 2,097 euros and women earn 1,298 euros. Furthermore, when we compare the average

\footnotetext{
${ }^{12}$ Possible answers for "main source of income" are employment income, retirement payments, rents, investment income, unemployment benefits, social welfare or financial grants.
} 
income of immigrants who migrated to Germany just 3 years before and after enlargement, it seems that the average income of male EU8 immigrants dropped from 1,648 euros to 1,407; while it increased for women from EU8 countries from 806 euros to 1,111 .

However, all these numbers are raw averages. As we will explain in detail in the next section, observable characteristics of all these groups are different, and this may lead to the wrong conclusion from just using raw averages. To address the differences in observable characteristics between different immigrant groups as well as the immigrants of the same group with different years of migration to Germany, we effectively control for the observable characteristics of immigrants in our analysis.

\section{Empirical Analysis}

In the previous section, we presented descriptive characteristics for different immigrants groups. As explained, all these groups differ in terms of their observable characteristics including educational attainment, age at migration, employment choices, location of migration choices, and so on. In this section, we compare immigrants' income, hourly wage, working hours, employment status, and self employment probabilities relative to natives and across immigrant groups. We present conditional means on these labor market measures using regression analysis, in which we compare immigrants to natives after controlling for observable characteristics. We analyze the natives and immigrant groups which were defined in the previous section. 
We report a cross-sectional analysis in Table 3 using the 2006 microcensus and follow the basic specifications for immigrant earnings equations widely applied in the literature: the variable of interest is regressed on individual characteristics such as sex, age, education, marital status; state dummies to control for fixed differences across German states; and dummies for each group. The reported standard errors are clustered by immigrant groups, accounting for the correlations in outcome of individuals within the same group. The dependent variable is the natural logarithm of monthly income (in column 1), natural logarithm of hourly wage (in column 2), weekly hours worked (in column 3), probability of employment (in column 4), and the likelihood of selfemployment (in column 5). In all these regressions, the omitted group is "natives”. In the first 3 regressions, reported coefficients can be interpreted as the mean difference in outcome of interest with respect to German natives. For the remaining regressions, it is the difference in the probability of being in work for each particular group of immigrants with respect to natives, once observable controls are included.

[Table 3 here]

The monthly income of recent EU8 immigrants is on average 28\% less than that of natives who have similar observable characteristics. In addition, earlier and recent EU8 immigrants earn less compared to other immigrant groups. In a similar vein, recent EU8 immigrants' hourly wage is the lowest among all immigrant groups, and recent EU immigrants earn on average $24 \%$ less relative to German natives. They also work on average 0.75 hours less a week than natives. Therefore, we may conclude that recent EU8 immigrants work on average more hours, and their hourly wage is less compared to nonnatives: hence, their monthly income is lower than other immigrant groups. 
In column 4 of Table 3, we analyze the employment status of immigrant groups. We construct an employment status indicator which takes the value of 1 if an individual is employed and zero otherwise. In Table 3, reported coefficients are the difference in probability of being employed for the relevant group relative to natives with similar observable characteristics. From column 4 of Table 3, it appears that recent EU8 immigrants are $23.7 \%$ less likely to be employed, and they have the lowest labor force participation among all immigrant groups. Having shown that immigrants from the EU8 have lower labor force participation, we quantify whether this immigrant group is substantially different from other immigrant groups with respect to other dimensions of employment, i.e. self-employment. The estimation results are displayed in column 5 of Table 3. This column suggests that recent EU8 immigrants are 15\% more likely to be self-employed relative to natives. This finding is not surprising as Germany has very few restrictions on being self-employed for EU8 migrants. However, it is still an open question why the recent immigrants from the EU8 outperform other immigrant groups in terms of self-employment.

There are additional checks that might help us to understand the nature of immigration to Germany and how it has altered since EU enlargement. To gain a better understanding of the effect of enlargement and the distribution of immigrants who migrated to Germany after 2004, we divide all immigrant sub-groups into two categories, recent and earlier, and report the results in Table 4. This specification can help us to account for the assimilation or the integration effects. First, earlier immigrants from the same source country with similar observable skills may earn more than the recent arrivals only because they have spent more time in the host country. Second, there might be differences in earnings between recent and earlier immigrants due to the fact that the 
earlier immigrants may have had better information about the local labor market in the host country, acquired the language skills required from the higher skilled jobs, and had better access to training in order to obtain country specific skills which are all unobservable in this data set.

[Table 4 here]

Table 4 suggests that the net monthly wage of recent EU8 and non-EU immigrants is $28 \%$ and $37 \%$ less, respectively, relative to natives with similar observables. Although recent EU8 immigrants work 1.8 hours a week more than recent non-EU immigrants, their mean levels of hourly wages are not statistically different from each other; hence, both groups' hourly wage is on average $24 \%$ less than that of natives. However, recent EU15 immigrants earn 6\% more a month than natives with similar characteristics. Furthermore, the hourly wage of recent EU15 immigrants is not statistically different from that of the natives, and they only work 0.1 hours more a week, which is statistically significant. These results on recent EU15 immigrants indicate that those who are generally better educated and are high-skilled have a higher income premium during the recent years of migrating to and working in Germany. On the other hand, the net-migration number of EU15 immigrants also indicates that unsuccessful ones have left Germany in recent years. Recent EU8 immigrants work in low-paid jobs and work longer hours, and their monthly income is the lowest on average among all immigrant groups except recent non-EU immigrants.

Table 4 also suggests that EU8 immigrants are 23\% less likely to work relative to natives, and this is also similar for recent EU15 immigrants. Earlier EU15 immigrants are $2 \%$ more likely to be self-employed than natives. Also, the probability of being self- 
employed for recent EU8 immigrants is 15\% higher than for natives and higher than all other earlier immigrant groups. However, recent EU8 immigrants have a lower probability of being employed compared to earlier immigrant groups.

We also estimate alternative specifications to address different concerns in the immigration literature. First, we investigate whether the results presented in Table 3 and Table 4 are driven simply by the fact that earlier/recent immigrant groups are more likely to work in specific industries and occupations. In this case, we might mistakenly attribute the differences in the earnings profile across industries/occupations to earnings differences between recent and earlier immigrants. The results in Table 3 and Table 4 are very similar after controlling for industry and occupation fixed characteristics in addition to other control variables, which further bolster our confidence that our results are not driven by differences in immigrants' occupations or industries.

Second, we control for individuals' years of schooling in our estimations. However, years of schooling may not be as a good measure of education, since source countries may have different time spans to obtain similar educational levels. Therefore, we estimate the same specifications but include 3 educational categories instead of years of schooling in our analysis. We find that coefficients in Table 3 and 4 are higher in absolute terms in this specification; nevertheless, the results are in accordance with previous specifications for all groups.

Finally, another confounding factor for the main analysis is potential differences in earnings profiles across different age groups. In particular, individuals' labor market earnings increase with age and experience. Therefore, if we do not account for this factor, a differential age composition of immigrant groups can lead to misleading conclusions, 
even though we exclude students and trainees from the analysis. We might conclude that recent immigrants earn less relative to earlier immigrants, while in reality the composition of EU8 immigrants has been changing, i.e. some immigrant groups comprise of younger individuals than others: hence, they have lower mean labor market earnings. To address this concern, we exclude from the analysis individuals younger than 25 who work in mini-jobs. The main results virtually remain unchanged after excluding these individuals, although some of the coefficients change slightly. This additional analysis further confirms that our results are not caused by the change in the age composition of EU8 immigrants or other immigrant groups.

\section{Conclusions and Policy Recommendations}

The number of migrants from the accessions countries has clearly increased since the enlargement of the EU in 2004. With enlargement, the net gain of EU8 immigrants has become 2.5 times larger than in the four-year period before enlargement. Among EU8 immigrants, Poles constitute the largest immigrant group: since enlargement, 71\% of EU8 immigrants and 65\% of all immigrants are from Poland. On the other hand, without the immigration from the EU8, Germany would have had a net loss of migration. Therefore, it is essential to understand how this new immigrant influx from the EU8 countries has affected the labor market conditions in Germany, and whether the composition of these immigrants has altered since enlargement. This chapter presents unique evidence on the impact of immigrant flows from EU8 countries on the German labor market after EU enlargement. 
Our analysis suggests that the composition of EU8 immigrants has indeed changed since EU enlargement. The recent immigrants from EU8 countries are comparably older and have lower levels of education relative to previous immigrants from EU8 countries. On the other hand, the majority of EU8 migrants are male and young, and come from either Poland or the Baltic states. The change in the distribution of recent immigrants is also reflected by their labor market outcomes in Germany. We find that recent EU8 immigrants work in low-paid jobs and work longer hours, and their net monthly income is the lowest on average among all immigrant groups except recent non-EU immigrants.

In a similar vein, recent EU8 immigrants are $23.7 \%$ less likely to be employed, and they have the lowest labor force participation among all immigrant groups except recent non-EU immigrants. On the other hand, recent EU8 immigrants are 15\% more likely to be self-employed relative to natives. EU8 immigrants work 1.8 hours a week more than recent non-EU immigrants, but their mean levels of hourly wages are not statistically different from each other, whereas both groups' hourly wage is $24 \%$ less than natives on average.

Taking these findings together suggests that recent EU8 immigrants in Germany are more likely to be self-employed than employed as a wage earner in Germany. Furthermore, these recent EU8 immigrants also earn less conditional on being employed or self-employed. Given the large numbers of inflows and outflows of recent EU8 immigrants, they may serve as seasonal workers in low-paid jobs or in agriculture. Our results suggest that recent EU8 immigrants are more likely to compete with immigrants from outside Europe for low-skilled jobs than compete with natives in Germany. 
Although Germany needs high-skilled immigrants, our analysis suggests that these immigrants only replace non-EU immigrants in low-skilled jobs. These results underline the importance of more open immigration policies targeting high-skilled immigrants. 


\section{References:}

Bonin, H., W. Eichhorst, C. Florman, M. O. Hansen, L. Skiöld, J. Stuhler, K. Tatsiramos, H. Thomasen and K. F. Zimmermann. 2008. "Geographic Mobility in the European Union: Optimising its Economic and Social Benefits”, IZA Research Report No. 19.

Blanchflower, D. J. and H. Lawton. 2008. "The Impact of the EU on the UK Labour Market”, IZA Discussion Paper No. 3695.

Bundesagentur für Arbeit. 2008: Arbeitsmarkt in Zahlen, Arbeitsgenehmigungen/ Zustimmungen 2007.

Brenke, K., and Zimmermann, K. F. 2007. "Zuwanderung aus Mittel- und Osteuropa trotz Arbeitsmarktbarrieren deutlich gestiegen”, DIW Wochenbericht, 44, 645-53.

Christen, T. G.. 2004. "Der Zugang zum deutschen Arbeitsmarkt nach der EUErweiterung”. In: Bundesarbeitsblatt, Nr. 3/2004, p. 10.

De Giorgi, G. and M. Pellizzari. 2006. "Welfare Migration in Europe and the Cost of a Harmonised Social Assistance”, IZA Discussion Paper No. 2094.

Fouarge, D., and P. Ester. 2007a.“ Determinants of Migration Intentions in Europe. Exodus or Bounded Mobility?” Institute for Labour Studies, Tilburg University, mimeo.

Fouarge, D., and P. Ester. 2007b. "Factors Determining International and Regional Migration in Europe”, European Foundation for the Improvement of Living and Working Conditions, Dublin.

Kahanec, M. and K. F. Zimmermann. 2008. "Migration in an Enlarged EU: A Challenging Solution”, IZA Discussion Paper No. 3913.

Zaiceva, A. and K. F. Zimmermann. 2008. "Scale, Diversity, and Determinants of Labour Migration in Europe”, Oxford Review of Economic Policy, 24 (3), 428-452. 
Table 1: Total Annual Inflow and Net Migration Numbers by Citizenship in Germany

\begin{tabular}{|c|c|c|c|c|c|c|c|}
\hline Citizenship & $\underline{\underline{2000}}$ & 2001 & 2002 & 2003 & 2004 & $\underline{2005}$ & 2006 \\
\hline & \multicolumn{7}{|c|}{ A. Total Annual Inflows } \\
\hline Poland & 70,431 & 75,012 & 77,405 & 84,693 & 119,551 & 141,314 & 145,761 \\
\hline Hungary & 15,514 & 16,455 & 15,982 & 13,790 & 16,834 & 18,026 & 18,111 \\
\hline Slovakia & 10,413 & 10,985 & 10,889 & 10,006 & 11,053 & 11,395 & 10,933 \\
\hline Czech. Rep. & 10,392 & 10,207 & 9,601 & 7,873 & 8,275 & 7,762 & 7,125 \\
\hline Slovenia & 1,770 & 2,504 & 2,197 & 1,975 & 2,260 & 1,397 & 1,080 \\
\hline Estonia & . & . & . & 738 & 667 & 635 & 529 \\
\hline Latvia & . & . & . & 1,642 & 2,085 & 2,248 & 1,857 \\
\hline Lithuania & . & . & . & 2,775 & 4,150 & 4,859 & 4,477 \\
\hline EU8 & 108,520 & 115,163 & 116,074 & 123,492 & 164,875 & 187,636 & 189,873 \\
\hline Romania & 22,521 & 18,547 & 22,376 & 22,329 & 22,203 & 22,052 & 22,532 \\
\hline Bulgaria & 10,008 & 12,516 & 12,371 & 12,613 & 10,891 & 8,492 & 7,260 \\
\hline Turkey & 39,575 & 44,189 & 47,616 & 41,908 & 36,275 & 30,002 & 26,059 \\
\hline Russia & 25,996 & 28,208 & 29,072 & 25,671 & 23,168 & 19,072 & 14,274 \\
\hline Other countries & 153,116 & 175,217 & 174,215 & 150,830 & 136,713 & 125,127 & 121,849 \\
\hline Germany & 132,773 & 134,616 & 128,238 & 118,019 & 131,752 & 92,953 & 77,082 \\
\hline EU15 & 115,359 & 105,896 & 97,127 & 86,745 & 81,643 & 78,175 & 78,535 \\
\hline Europe & 400,957 & 411,951 & 402,009 & 375,376 & 396,597 & 392,656 & 380,117 \\
\hline \multirow[t]{2}{*}{ Total } & 686,846 & 721,784 & 704,462 & 644,225 & 665,062 & 610,736 & 579,048 \\
\hline & \multicolumn{7}{|c|}{ B. Total Annual Net Migration } \\
\hline Poland & 11,841 & 12,836 & 11,461 & 13,003 & 26,600 & 44,951 & 40,569 \\
\hline Hungary & 1,500 & 2,010 & 685 & -770 & 793 & 2,716 & 3,426 \\
\hline Slovakia & 2,000 & 1,548 & 1,462 & 806 & 1,240 & 2,522 & 1,696 \\
\hline Czech. Rep. & 2,070 & 2,154 & 1,113 & 58 & 433 & 1,868 & 1,034 \\
\hline Slovenia & -32 & 255 & 26 & $-5,867$ & 76 & -37 & 1 \\
\hline Estonia & . & . & . & 268 & -38 & 203 & 60 \\
\hline Latvia & . & . & $\cdot$ & 292 & 510 & 891 & 379 \\
\hline Lithuania & . & . & . & 831 & 1,888 & 2,465 & 1,437 \\
\hline EU8 & 17,379 & 18,803 & 14,747 & 8,621 & 31,502 & 55,579 & 48,602 \\
\hline Romania & 6,900 & 1,319 & 5,840 & 3,634 & 2,896 & 2,334 & 1,627 \\
\hline Bulgaria & 3,511 & 4,819 & 4,027 & 2,860 & 1,137 & 2,746 & 226 \\
\hline Turkey & 7,992 & 14,871 & 17,526 & 11,650 & 5,666 & 2,766 & 881 \\
\hline Russia & 15,816 & 17,770 & 17,202 & 14,094 & 11,360 & 8,366 & 4,078 \\
\hline Other countries & 53,820 & 76,198 & 71,707 & 43,516 & 20,558 & 21,075 & 16,269 \\
\hline Germany & 47,930 & 49,330 & 37,330 & 19,484 & 13,524 & $-17,796$ & $-41,009$ \\
\hline EU15 & 5,868 & 2,345 & $-8,486$ & $-10,019$ & $-25,507$ & $-4,401$ & $-2,524$ \\
\hline Europe & 29,867 & 78,832 & 62,272 & 45,497 & 33,231 & 70,124 & 56,461 \\
\hline Total & 131,617 & 204,360 & 171,309 & 108,497 & 67,313 & 73,403 & 31,721 \\
\hline
\end{tabular}

Notes: Authors' calculation using Statistisches Bundesamt (Federal Statistical Office) - Population Register. Outflow numbers are inflow minus net migration numbers. "Other countries" include remaining countries, stateless individuals and individuals with unknown nationality. Total row comprimised of individuals from Europe, Germany and Other Countries. 
Table 2: Employment and Residential Characteristics in Germany by Citizenship

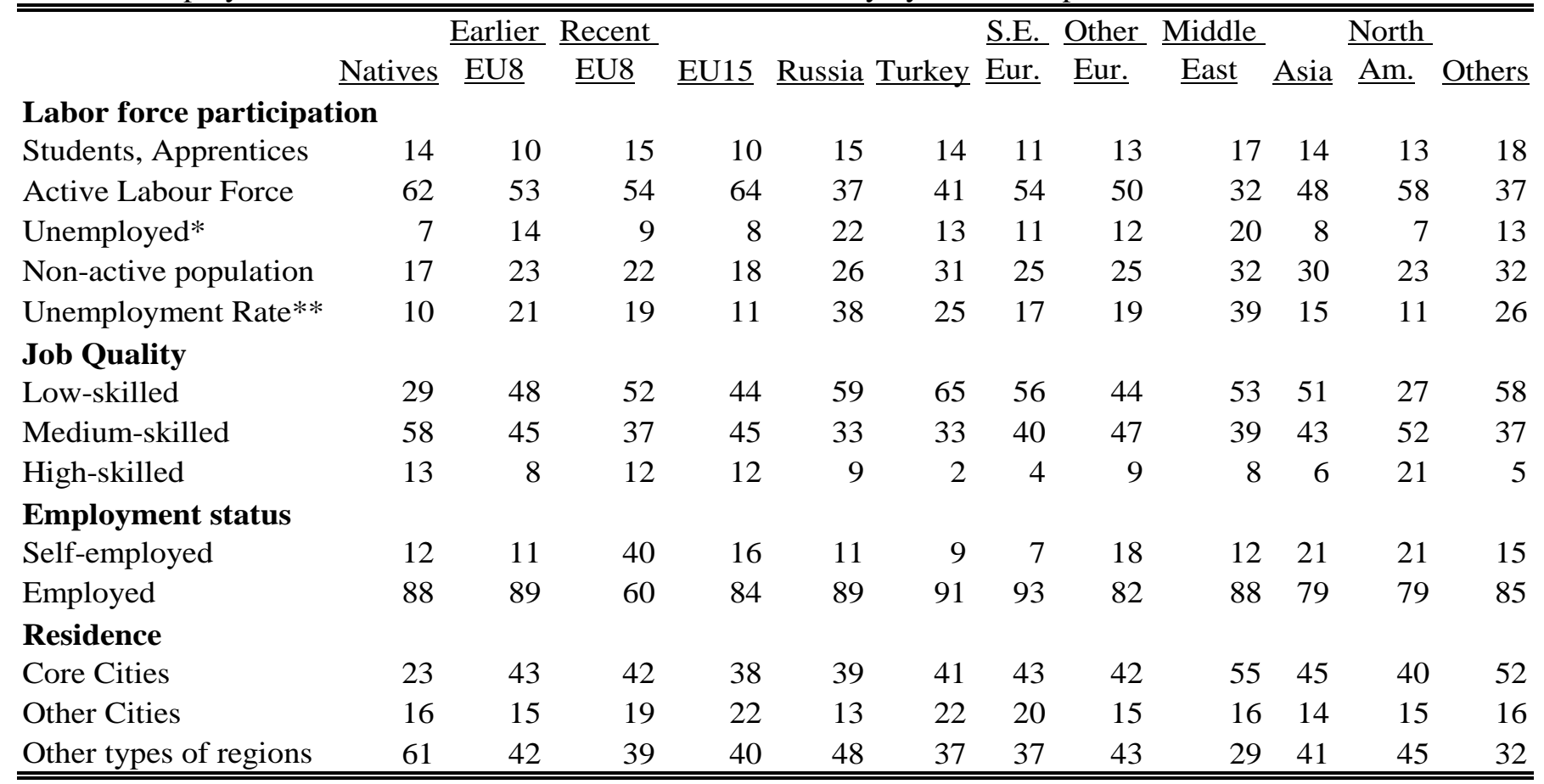

Notes: Authors' calculation from 2006 microcensus. All numbers are in percentages. "Recent EU8" shows immigrants migrated after 2004 from EU8 countries. "Earlier EU8" shows immigrants arrive before 2004 from EU8 countries. "S.E. Eur." includes former Yugoslavia countries (without Slovenia), Bulgaria, and Romania. " Other Eur" indicates remaining EU countries.

"Middle East" includes Middle East and North African countries. "Job Quality" is classified by skill intensity of occupations.

* includes employed students.

** excludes employed students. 
Table 3: Labor Market Outcomes by Citizenship

\begin{tabular}{|c|c|c|c|c|c|c|c|c|c|c|}
\hline \multirow[b]{2}{*}{ EU8-Recent imm. } & \multicolumn{2}{|c|}{$\begin{array}{l}\text { Logincome } \\
\end{array}$} & \multicolumn{2}{|c|}{ 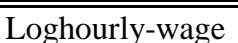 } & \multicolumn{2}{|c|}{ Work Hours } & \multicolumn{2}{|c|}{ Employment } & \multicolumn{2}{|c|}{$\overline{\text { Self Employment }}$} \\
\hline & -0.278 & $(0.005)$ & -0.246 & $(0.006)$ & -0.740 & $(0.038)$ & 233 & $(0.006)$ & 0.158 & 004) \\
\hline EU8-1 & -0.211 & 600 & -0.166 & & 198 & & 28 & & -0.009 & \\
\hline Non- & -0.125 & (0.0 & -0.100 & & -0.776 & & 45 & & -0.020 & \\
\hline EU1 & -0.027 & $(0.0$ & -0.037 & & 0.612 & $(0.0$ & -0.032 & & 0.027 & $(0.000)$ \\
\hline Nativ & -0.100 & $(0.0$ & -0.086 & $(0$. & -0.630 & (0. & 63 & & -0.021 & 00) \\
\hline $\mathrm{Gen}$ & 469 & $(0 . C$ & -0.180 & $(0$. & -8.597 & & -0.129 & & -0.041 & 0) \\
\hline & 0.266 & (0.0 & 0.147 & & 1.998 & & 01 & & 0.058 & $(0.003)$ \\
\hline ears & 0.081 & $(0.006)$ & 0.066 & $(0.005)$ & 0.489 & $(0.035)$ & 0.028 & $(0.003)$ & 0.009 & $0.000)$ \\
\hline
\end{tabular}

Notes: Number of observations are 240,413 for first three regressions and 421,840 for last two regressions. Standard errors clustered by state are shown in parentheses. Each regression also controls for polynomial of age up to degree four, and 16 state indicators. "EU8-Recent" shows immigrants who arrived after 2004 from EU8 countries. "EU8-Earlier" shows immigrants who arrived before 2004 from EU8 countries. "EU15 imm" shows all immigrants from EU15 countries. "Non-EU imm." indicates immigrants outside the EU. "Native-Other" indicates German citizens who obtained German nationality after birth. The omitted group is German natives in all regressions.

Table 4: Labor Market Outcomes by Citizenship for all Immigrant Groups by Arrival Status.

\begin{tabular}{|c|c|c|c|c|c|c|c|c|c|c|}
\hline \multirow[b]{2}{*}{ EU8-Recent imm. } & \multicolumn{2}{|c|}{ Logincome } & \multicolumn{2}{|c|}{ Loghourly-wage } & \multicolumn{2}{|c|}{ Work Hours } & \multicolumn{2}{|c|}{ Employment } & \multicolumn{2}{|c|}{ Self Employment } \\
\hline & -0.277 & $(0.003)$ & -0.245 & $\overline{(0.005)}$ & -0.745 & $(0.037)$ & -0.231 & $(0.008)$ & 0.157 & $(0.005)$ \\
\hline EU8-Earlier imm. & -0.210 & $(0.001)$ & -0.166 & $(0.001)$ & -1.199 & $(0.014)$ & -0.127 & (0.007) & -0.009 & $(0.001)$ \\
\hline Non-EU Earlier imm. & -0.126 & $(0.007)$ & -0.104 & $(0.006)$ & -0.741 & $(0.041)$ & -0.125 & $(0.002)$ & -0.021 & 01) \\
\hline Non-EU Recent imm. & -0.371 & $(0.003)$ & -0.256 & $(0.005)$ & -2.595 & $(0.076)$ & -0.442 & $(0.012)$ & -0.037 & $(0.002)$ \\
\hline EU15-Earlier imm. & -0.031 & $(0.004)$ & -0.045 & $(0.002)$ & 0.794 & $(0.033)$ & -0.023 & $(0.001)$ & 0.025 & $(0.001)$ \\
\hline EU15-Recent imm. & 0.058 & $(0.009)$ & 0.114 & $(0.004)$ & -1.627 & $(0.138)$ & -0.220 & (0.008) & -0.010 & $(0.002)$ \\
\hline Native-Other & -0.099 & $(0.003)$ & -0.085 & $(0.003)$ & -0.630 & $(0.024)$ & -0.061 & $(0.003)$ & -0.021 & $(0.000)$ \\
\hline Gender & -0.469 & (0.009) & -0.179 & $(0.007)$ & -8.597 & $(0.050)$ & -0.129 & $(0.006)$ & -0.041 & $(0.000)$ \\
\hline Age & 0.263 & $(0.01$ & 0.144 & $(0.024)$ & 2.019 & (0.373) & 0.003 & $(0.024)$ & 0.059 & $(0.002)$ \\
\hline Years of Education & 0.081 & $(0.006)$ & 0.066 & $(0.005)$ & 0.492 & $(0.032)$ & 0.029 & $(0.002)$ & 0.009 & $(0.000)$ \\
\hline
\end{tabular}

Totes: Number of observations are L40,413 ror ilrst three regression and 421,840 lor last two regressions. Standard errors clustered by state are shown in parantheses. Each regression also controls for polynomial of age up to degree four, and 16 state indicators. "EU8-Recent imm.", "EU15-Recent imm.", " Non-EU Recent imm." show immigrants who arrived after 2004 from EU8 countries, from EU15 countries, and outside the EU respectively. "EU8-Earlier imm.", "EU15-Earlier imm.", " Non-EU Earlier imm." shows immigrants who arrived before 2004 from EU8 countries, from EU15 countries, and outside the EU, respectively. "Native-Other" indicates German citizens who obtained German nationality after birth. The omitted group is German natives in all regressions. 
Figure 1: The Stock of EU8 Immigrants in 2006 by Year of Arrival and Gender

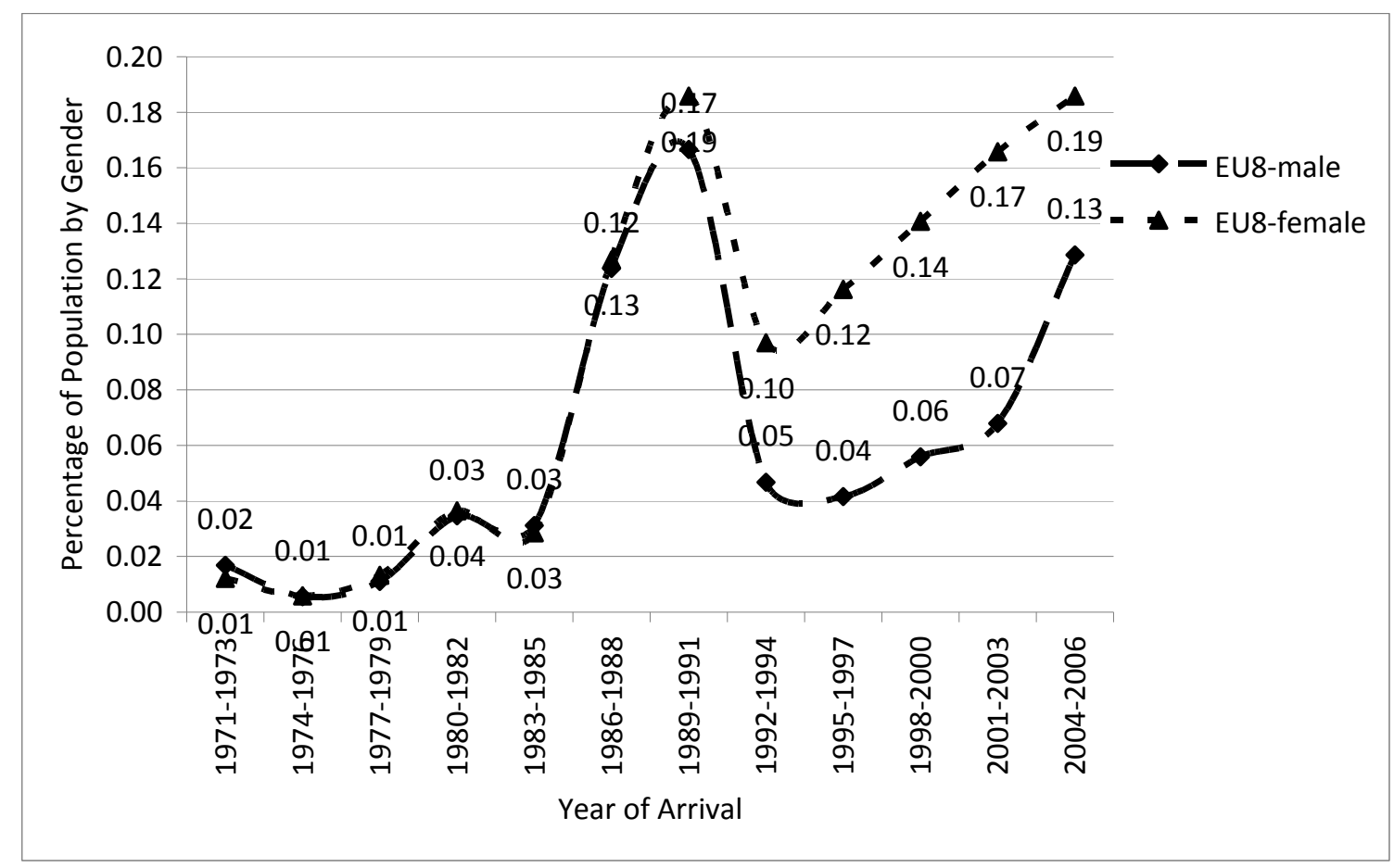

Notes: The X-axis shows the year of arrival in 3-year intervals and the Y-axis shows the percentage of total population by gender. In order to calculate the stock, we take the number of male immigrants in 2006 from a year of arrival interval and divide this by total number of males in 2006 and then multiply this share by 100 to express it in percentage points. Female stock percentages are calculated similarly. 
Figure 2a: Average Years of Schooling of Male Immigrants by Year of Arrival and Country of Origin

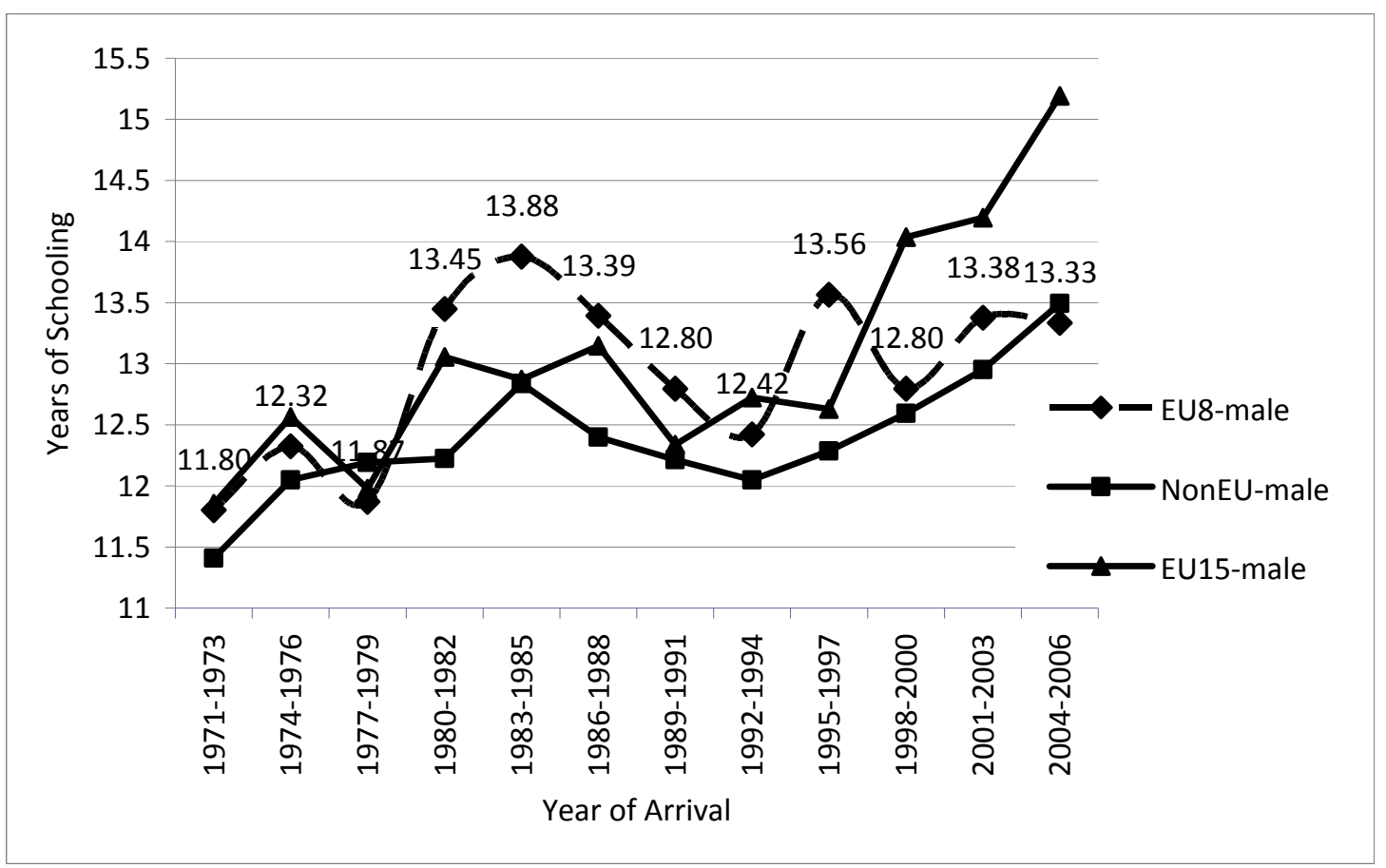

Notes: The $\mathrm{X}$-axis shows the year of arrival in 3-year intervals and the $\mathrm{Y}$-axis shows average years of schooling in 2006. "EU8-male”, "EU15-male”, "NonEU-male” indicate average years of schooling of male immigrants from the EU8, EU15, and remaining countries respectively. 
Figure 2b: Average Years of Schooling of Female Immigrants by Year of Arrival and Country of Origin

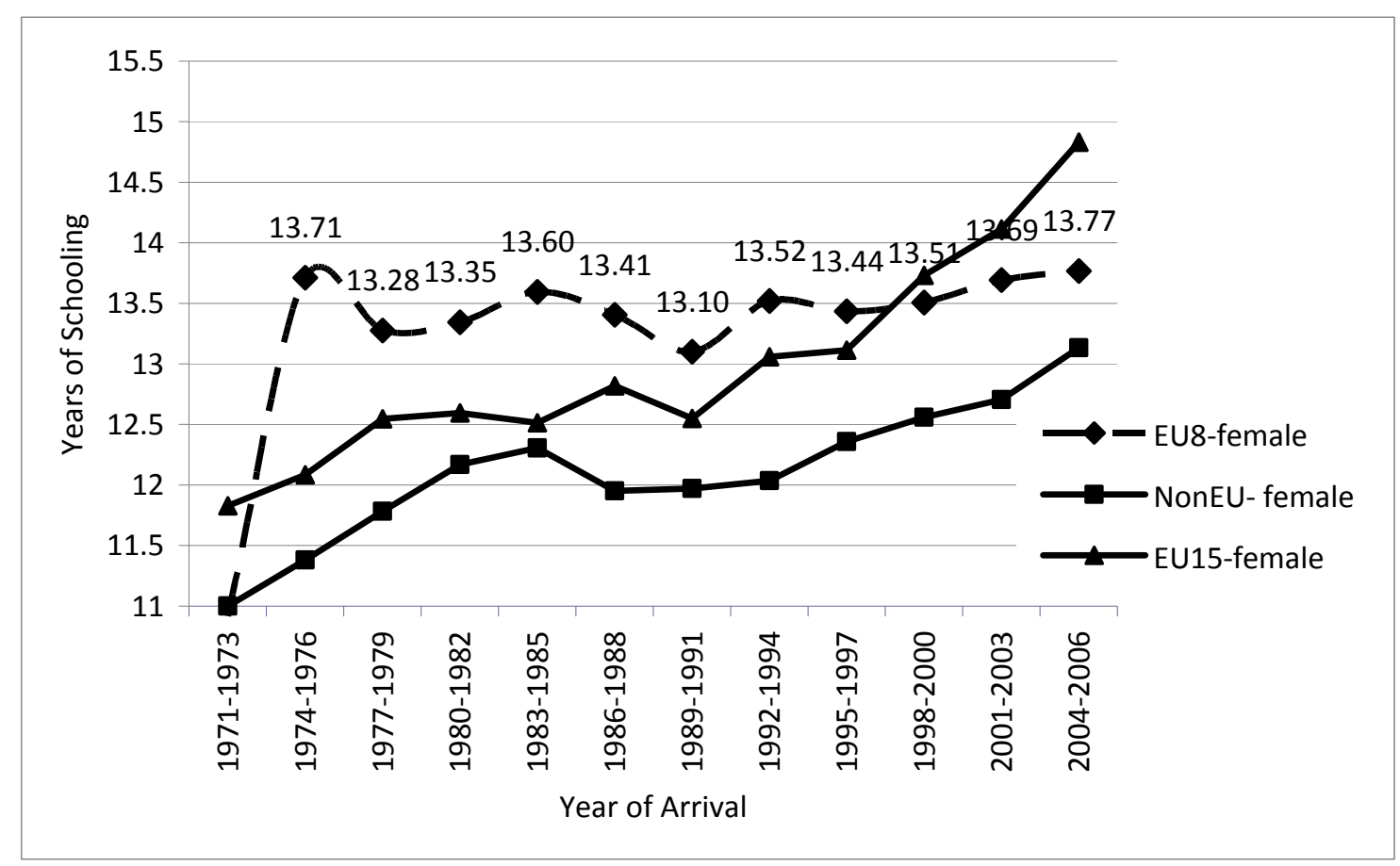

Notes: The X-axis shows the year of arrival in 3-year intervals and the Y-axis shows average years of schooling in 2006. "EU8-female”, "EU15-female”, “Non-EU-female” indicate average years of schooling of female immigrants from the EU8, EU15, and remaining countries respectively. 